\title{
Violation of justice in American police department as reflected in the film Changeling
}

\author{
Nurullita ${ }^{\text {a, },{ }^{*}}$ \\ ${ }^{a}$ Litelature English Departement Ahmad Dahlan \\ ${ }^{1}$ nurullita@com.uad.ac.id*; \\ * corresponding author
}

Article history

Received 21-09-2020

Revised 12-11-2020

Accepted 13-11-2020

Keywords

Violation of Justice

Propaganda

Police injustice

\begin{abstract}
This undergraduate thesis describe justice theory and propaganda theory. This is aiming at analyzing violation of justice and propaganda police towards the main character and society in American. This undergraduate thesis has two main objectives to portray the violation of justice and the police propaganda in America as reflected in the Changeling film. This research uses descriptive qualitative method. There are two types of data in this study, they are primary and secondary data. The primary data is taken from the film Changeling and secondary data are taken from books, articles, journals, and data from network sources. In this research the, writer uses an interdisciplinary study. In conducting the analysis, researchers used the theory of justice and propaganda theory. To analyze this topic, the researcher uses John Rawls's theory of justice, which is actually contradict with what happens in this film. Then the researchers used propaganda theory from Jowett and O'Donnell, which the theory shows the behavior of the police against the main characters. The result of the study shows that is Los Angeles Police Department does not serve the society wisely. They use their power to be inappropriate. It acts in a violent way, and intimidates its citizens. The evil man are protected and the good is shot dead. Justice is not always run by violating people's right. This research also finds that people who have been given a great power, they tend to abuse the power. Moreover, in human relationship, the concept of equal treatment must be applied to avoid conflicts. People who get unfair treatment tend to fight against the bad treatment. Everyone has rights to be treated equally. Upholding justice is not always done by violation their rights. This research also finds that fairly equal treatment is valuable. People should be treated equally in any condition.
\end{abstract}

This is an open access article under the CC-BY-SA license.

\section{Introduction}

Talking about security we are certainly familiar with the police, because one of the important instruments in a country must have it. With the priority of maintaining security and public order, they work day and night for professionalism and loyalty a tough task to run. Apart from that, not all communities have the same assessment of police performance. Pros and cons definitely exit. Especially the police as a state apparatus cannot be separated from the media and the public spotlight. Positive values are how the police maintain their credibility in public (Hart, 2015).

However, it is very different from the image of the police department in this Changeling film. The police has not accounted for the authority they have to do. Serving the people wisely and fairly is his responsibility, but the society do not get that. The police department in the film is controlled 
by violence, abuse, corruption, and intimidation. In this film, there is a case one of the most prominent societies which will keep main character from getting rights from LAPD crime. Because in this film most of the people of Los Angeles do not get the rights of citizenship from the police department (Berg, 2014).

\section{Theorotocal Framework}

In this second chapter, the researcher exposes some theories. First, the researcher discusses the justice theory by Rawlsian. The last the researcher exposes the explanation about propaganda by Jowett and O'Donnell.

\section{1) American justice Justice in Amerika}

In the book The Past, Present and Future of American Justice, Maguire and Radosh (1996) stated that crime is law violation. This is known as the legalistic definition of crime and is probably the most common way in which behavior is defined used by the criminal justice system. The most conspicuous examples of legalistic crimes are the- index crimes. Dating back to 1930s, the government has collected official police statistic on certain crimes thoughts to be the most serious criminal offenses (Maguire \& Pitceathly, 2002).

\section{2) Rawls' Theory of Justice}

In a Theory of Justice (Schneider, 2018), John Rawls gives a theory of justice where justice is to be considered in terms of fairness. The first part of the work is based upon Rawls' nations of formal justice. Formal justice is the purely hypothetical formulation of principles of justice which is meant to serve as a foundation for Rawls' latter calls. According to Rawls, formal justice can be found in a hypothetical social contract which Rawls calls- the original position. Rawls structures "the original position" in order to show how justice will be understood in terms of fairness. In formal justice, all hypothetical individuals will be more or less equal due to the restrictions Rawls places upon people in the original position. Rawls says that the first principle is to take priority over the second. According to Rawls in order on society to be just, individual liberties must be protected for all members of society. By protecting individual liberties it is possible to say that all members of society are more or less equal. Rawls says that the first principle is prior to the second. The second principle deals primarily with social and economic differences which will be part of any society.

\section{a) Propaganda Theory}

According to Jowett \& O'Donnell's thought, "Propaganda is defined to give a message and suggest, it contains negative and dishonest contents. Propaganda frequently is used as lies, distortion, deceit, manipulation, mind control, psychological, sociological, brainwashing, and palaver through mass media "film". The terms propaganda and persuasion have been used interchangeably in the literature on propaganda, as well as in everyday speech. Propaganda employs persuasive strategies, but it differs from persuasion in certain purpose" (Jowett \& O’Donnell, 2012).

a. Forms of Propaganda

According to Szanto, although propaganda takes many forms, it is almost always in some form of activated ideology. "Sometimes propaganda is agitative, attempting to rouse an audience to certain ends and usually resulting in significant change; sometimes it is integrative, attempting to render an audience passive, accepting, and non-challenging" (Szanto, 1978: p.10). There are three forms of propaganda. According to (Jowett \& O'Donnell, 2012) in Propaganda and Persuasion there are three forms of which are categorized based on the methods it is used to shape its argument, such as; black, gray, or white.

\section{b. Black Propaganda}

Black propaganda is when the source is concealed or credited to a false authority and spreads lies, fabrications, and deceptions. Black propaganda is the "big lie," including all types of creative deceit (Ablon \& Bogart, 2017).

\section{c. Grey Propaganda}


Grey propaganda is somewhere between white and black propaganda. The source may or may not be correctly identified, and the accuracy of the information is uncertain. Grey propaganda is also used to embarrass enemies or competitor (Jowett \& O’Donnell, 2012).

\section{d. White Propaganda}

White propaganda comes from a source that is identified correctly, and the information in the message tends to be accurate. In the shape of this propaganda, source of propaganda conveys clearly and openly, propaganda is often called a model of overt propaganda and also commercial propaganda. This is what one watched, although what viewers see in this film is reasonably close to the truth, it is presented in a manner that attempts to convince the audience that the sender is the "good guy" with the best idea and political ideology. White propaganda attempts to build credibility with the audience, for this could have usefulness at some points in the future (Jowett \& O'Donnell, 2012).

\section{Method}

The researcher also obtains, collects, and gates important data from books, journals, magazine, and electronics source such as internet related to the topic of this thesis Violation of Justice in American Police Department as Reflected in the Film Changeling. There are some steps in whole process of doing this research as follows:

\section{1) Data and Source of Data}

The researcher collets data collected from primary source search. The researcher chooses to use the film as the main data, the researcher has been collecting primary data in the form of a film entitled Changeling by Clint Eastwood, that's an American drama film, in English language and duration is two hours and twenty one minutes.

\section{2) Supporting data}

In addition to collecting main data from the movie, the researcher also has collected some data from sources such as other supporting data, articles, journals, books, the internet, and related to the object of research. Supporting data is used to help the researcher to explain from the main data and describes the relationship between movie, phenomena, and life portray in America.

\section{3) Method of Collecting Data}

To collect the data, the researcher watches Changeling film several times and observe some related scenes. The researcher also reads some critics and reviews from the experts. To get the secondary data, the researcher uses library research and surfs the internet. The researcher went to some library to find out the information by reading books. These data are taken from some library such as Ahmad Dahlan University Library, Grahatama Pustaka and Gajah Mada University Library. The data are compiled together, classified, analyzed and finally written into this undergraduate thesis. There are two kinds of method in analyzing data, there are qualitative and quantitative. Qualitative method is describing the data collected in the form of words to decription about the research object (Nasution, 2002). In analyzing data the writer uses qualitative method.

\section{Results and Discussion}

A. The Portrayal of Violation of Justice in America As Reflected in Changeling Film

1) Cases Found in the Changeling That Contradict the Two Main Points of Justice Theory by John Rawls a) Unfairness

In the film Changeling it has been shown how the police strongly do not show where justice can be understood as justice. From some scenes, it will show that the police are really unfairly where justice as fairness was nothing. It's the illustrates that doctor Steele told and asked Christin Collins repeatedly to sign a letter of an agreement declaring that Christin Collins was wrong and the police were right in the search for her son. That doctor Stele was asked by Captain Jones from the LAPD, to tell and force Christin Collins to sign the file. 
Whereas, Rawls argues that justice consists of the basic principles of government that free and rational individuals would agree to in a hypothetical situation of perfect equality. Can be concluded that, John Rawls theory here is very contradictory fairness to the reality of the film that is here.

\section{b) Lawless}

The strong have trampled the weak, law and order disguised as justice. Often the wisest and the strongest are the rulers, and it is he who makes the important decisions. We can see that the Los Angeles Police Department is a very well -a known institution with a very orderly law and order. But since the LAPD is led by Sheriff James Davis, the LAPD is known as a rude, corrupt and incompetent police department. The police here look that they were not in accordance with their own will, not following the rules of law. In the leadership of James Davis, the police are known as the very cruel police. They have a firefighter, which is the wrong person or not they do not care. If they appear to be obstructing the police work without further noise immediately shot to death (Hoff \& Stiglitz, 2008).

\section{c) Cops being criminals}

The people who were fired by the police did not go through legal channels to be punished. The police played unilaterally, that people who hindered the performance of the police would be shot dead directly, whether they were blocking the police work properly or not. The real criminals here is the LAPD, the LAPD does not want to clean up the crime, the LAPD wants to clear the competition. In the last picture (00.43.13) it is very clear that the police release the real criminals. When the criminals do prostitution, gambling, bootlegging, the police actually protect them with the condition that criminals pay tribute/gave money. That the real fact that committed the crime here is LAPD.

\section{d) Compelling}

Each person is to have an equal right to the most extensive basic liberty compatible with a similar liberty for others. For Rawls to protect rights and liberties above the social gains is the fundamental way to ensure that a society is just. If individual rights and liberties are the main interest of institutions, inequalities in economic and social status can be more or less justified. For Rawls, individual rights. In this Changeling film, LAPD was an institution that should be able to protect the society, but Captain Jones as an institution can protect Christin Collins from injustice but here Captain Jones as a policy is a place of refuge but captain Jones as their own injustice and put Christin Collins in injustice (Nieman \& Wentz, 2019).

\section{B. Racial discrimination: The designation of "Code 12" is contains all women}

The police in here strongly suggest that they have committed many violations of justice. Captain Jones uses an incredible trick to avoid the injustice he made himself in the case of Christin Collins. Where Captain Jones joins Christin Collins without a warrant or government permission. Captain Jones made his own decision to bring an innocent woman into a mental hospital, where she had to fight to get her son back but captain jones by his heart's inclusion of Christin to a mental hospital. Which means that with Code 12 is the name of all women because of their case with the police, where the politicians did not want to be seen as guilty of the mistakes they made. And instead, put the innocent person into a mental hospital.

2) The Police Propaganda in America as Seen in Changeling Film.

The information that has been announced to the public through the mass media propagandist is as if it were not able to be refuted again and true facts. We know that the purpose of the police not to promote understanding, but it's to promote his own ends. Christin Collins was used as a bait to promote the LAPD that the police in Los Angeles have to look good in the citizens of Los Angeles. Because the Los Angeles police in the leadership of James Davis is getting worse and to raise the status of the LAPD in front of the Los Angeles society the police make the act of, one of them is propagating case of Christin Collins through the mass media, that LAPD look good again in front of the society in Los Angeles.

\section{a) Media become the main center of propagandist}

Media of modern propaganda which used in this film are radio, newspapers, and reporters. The police used the mass media to carry out their propaganda action so that the public was thinking from the beginning that the police had been very fast and responsive in carrying out their task of finding a

Nurulitta (Violation of justice in American police department as reflected in the film Changeling) 
child from Christin Collins. The main focus here is how the police used the media as much as possible to carry out propaganda action through newspaper and radio media to drop the main character through the media and the media spread to the public. There is three propaganda According to Garth S. Jowett and Victoria O'Donnell.

\section{a. Black Propaganda}

Black propaganda is when the source is hidden, in the film proved on when the captain Jones conceals that he forced Christin Collins to bring her son home and the media did not know about it. The impression was hidden from the media/reporters. There are some evidence that show kind of black propaganda by police toward Christin Collins as seen in the film Changeling. They are described as below.

\section{b. Grey Propaganda}

The reason Christin Collins spoke in front of the mass media was that Captain Jones avoid continuously to Christin Collins to find her son again. Which is that Captain Jones found was not her real son. Christin Collins brave to spoke in front of the mass media because at the beginning of her case, Captain Jones took her to the mass media, Christin Collins thought to give back a wrong child and find her son back is the way she reveals the truth in the mass media. She said too that she's given LAPD the opportunity to apologize and admit their mistake and repeat their research. But Captain Jones did not accept Christin Collins's treatment. After Christin Collins gave a real explanation on the mass media, she was called by the police there is Captain Jones. For a moment she was immediately taken to mental hospital allegations of stress and lost control. Because the police didn't want Christin Collins to reveal more of what was going on and make the image of the police worse. And to fool the mass media, Christin Collins was immediately taken to a mental hospital, so that the mass media thought she was crazy and had revealed what was not real. She was taken through the back door of the police station. And when Jones meets Christin Collins, his gaze was very angry and very emotional because he felt humiliated in public.

\section{c. White Propaganda}

Sheriff Davis is the leader of the Los Angeles Police Department who gave information in front of mass media in a genuine and very convincing way that he will serve the society of Los Angeles sincerely and good. Explaining that it will do to the society of Los Angeles, but it is only propaganda/ tricks from him. In the reality was not. In here it is very visible that the police want to raise the status or degree in front of the Los Angeles society is already bad. Even when Sheriff Davis speaks in public tend to promote the performance of Los Angeles police officers, even if the police chief has intervened himself in public. Automatically the society of Los Angeles strongly believes the case is true. Sheriff Davis brave to spoke in front of the mass media with untrue information. This scene proof that is open propaganda from Sheriff Davis.

\section{Conclusion}

In this conclusion, the researcher offers all readers to be aware of injustices and respectable toward human rights. Even you have power, don't take it for granted and for your own desire. We have to understand that each person in this world has the same equal rights no matter their races, religion, ethnics, or genders are. People should be treated equally. Although they commit criminals, they should only be prosecuted by the legal laws, not by beating and violating them. Remember that they are also humans who deserve to be treated fair. We can start with ourselves so that the rest will follow us.

\section{References}

Ablon, L., \& Bogart, A. (2017). Zero Days, Thousands of Nights: The Life and Times of Zero-Day Vulnerabilities and Their Exploits. In Zero Days, Thousands of Nights: The Life and Times of Zero-Day Vulnerabilities and Their Exploits. https://doi.org/10.7249/rr1751

Berg, N. (2014). Predicting crime, LAPD-style. The Guardian.

W: http://journal2.uad.ac.id/index.php/commicast/index |E: commicast@comm.uad.ac.id | 
Hart, L. (2015). Social media. In Reputation Management: The Key to Successful Public Relations and Corporate Communication. https://doi.org/10.4324/9781315879987-12

Hoff, K., \& Stiglitz, J. E. (2008). Exiting a lawless state. Economic Journal. https://doi.org/10.1111/j.14680297.2008.02177.x

Jowett, G. S., \& O’Donnell, V. (2012). What Is Propaganda, and How Does It Differ From Persuasion? Propaganda and Persuasion.

Maguire, P., \& Pitceathly, C. (2002). Key communication skills and how to acquire them. British Medical Journal. https://doi.org/10.1136/bmj.325.7366.697

Nasution, S. (2002). Metode Penelitian. Jakarta: Rineka Cipta.

Nieman, D. C., \& Wentz, L. M. (2019). The compelling link between physical activity and the body's defense system. Journal of Sport and Health Science. https://doi.org/10.1016/j.jshs.2018.09.009

Schneider, A. (2018). Fundamentals. In Springer Handbooks. https://doi.org/10.1007/978-3-662-55004-5_30 